\title{
Social Information Processing and Aggravation of Conduct in Young Offenders
}

\author{
Mariana Guedes de Oliveira Franco* and Marina Rezende Bazon \\ University of São Paulo \\ *Corresponding Author: Marina Rezende Bazon, University of São Paulo, Faculdade de Filosofia, \\ Ciências e Letras de Ribeirão Preto, Departamento de Psicologia, Avenida dos Bandeirantes, 3900, \\ CEP 14040-901, Ribeirão Preto, SP, Brazil. E-mail: mbazon@ffclrp.usp.br
}

(Submitted 1 October 2017; revised 4 October 2017; accepted 6 October 2017)

\begin{abstract}
The present study investigated the differences in patterns of social information processing (SIP) among adolescents with two trajectories of offending: group 1 (G1) composed of adolescents with a trajectory of major persistent offenses, which includes illegal acts considered violent; group 2 (G2) composed of individuals with a trajectory of minor persistent offenses, in which there is no escalation of the gravity of the offenses; and a comparison group (G3) with adolescents without involvement in offenses. SIP is one of the theoretical models most widely evoked to study and explain violent behavior in children/adolescents, in regarding the psychological processes that underlie behavior, specifically the cognitive nature. The participants answered a self-report delinquency interview and a SIP measure protocol. The results showed differences between the groups of offenders (G1 and G2) and the comparison group (G3) on the SIP pattern related to the competent responses. G1 and G2 revealed a SIP pattern poorly associated with socially competent behavior. However, G1 presented an SIP pattern more associated with the emission of aggressive behaviors. This pattern, although also present in G2, is more evident for those adolescents who reported committing crimes with the use of violence against people.
\end{abstract}

Keywords juvenile delinquency; social information processing; social cognition; conduct aggravation

The manifestation of risky behaviors, including deviant practices that can be characterized as offenses, is quite common during adolescence and it characterizes a statistically normative process (Loeber, Keenan, and Zhang 1997; Mun, Windle, and Schainker 2008). Approximately $70-95 \%$ of adolescents are expected to engage in activities that violate laws (Komatsu 2014; Le Blanc 2003). For most of them, this is an occasional behavior which occurs in a life context of respect for the law and social rules, and is motivated by the pursuit of pleasure and excitement, very frequently in the presence of friends. This behavioral pattern characterizes what has been commonly called common or normative delinquency (Fréchette and Le Blanc 1987 as 
cited in Panosso 2008). The practice of offenses in these cases tends to cease spontaneously, being circumscribed by adolescence (Le Blanc 2003).

However, delinquent behavior can evolve, so it is possible to identify different trajectory patterns, referring either to a lower or higher degree of delinquent engagement (Bazon et al. 2011). The most significant delinquent engagement refers to what is conventionally called persistent delinquency. It concerns, in general, a small subgroup of adolescents, for whom the stability of offensive behavior is verified over time. Despite being the minority, adolescents with this behavioral pattern are responsible for a significant volume of offenses (Fréchette and Le Blanc 1987 as cited in Panosso 2008). The behavior which describes a persistent offense trajectory is precociously manifested; that is, the first offense occurs in the early years of adolescence and, in some cases, in childhood itself. Thereafter, the practice of infractions is characterized by a greater frequency and diversity (Le Blanc 2003).

Based on his large amount of empirical research, Le Blanc (2010) points out that variabilities also occur among adolescents whose behavior describes a persistent offense trajectory. He distinguishes two groups of persistent adolescent offenders based primarily on the aggravation of the acts. The subgroup whose behavior describes a persistent trajectory that is aggravated is composed of adolescents who have been engaged in deviant activities very early, gradually engaging in other various forms of illicit activities. These activities, at a certain point, in the second half of adolescence, include a direct approach to victims, denoting a transition from offenses against property to others involving people directly, such as robberies, kidnappings, rapes and homicides. This subgroup, termed major persistent, is responsible for the great majority of known violent offenses practiced by adolescents (Le Blanc 2010). In the other subgroup, called minor persistent, the involvement in deviant activities is somewhat less precocious; their behavior is characterized by stability implying, therefore, in great a volume but a low variety of offenses. Their behavior includes offenses against property, with methods free of interpersonal violence (dispensing the use of physical force or threats) (Le Blanc 2010).

The findings about the variability of the manifestations of offense behaviors impose the need to try to better understand what psychological and social mechanisms are involved in these differentiated processes. Despite the wide range of social variables that is certainly involved in the production of the major persistent delinquency (such as "exposure to violent models"), the present research focuses on the psychological mechanisms. It postulates a link between problems related to the regulation of aggressiveness (due to the cognitive schemes structured since childhood), and the development of a (major) persistent offense trajectory, which includes acts considered to be violent in adolescence.

Nowadays, one of the most widely evoked theoretical models for studying and explaining aggressive behavior in children and adolescents, regarding the psychological processes that underlie behavior, specifically those of a cognitive nature, is the social information processing (SIP) theory (Calvete and Orue 2012; Crick and Dodge 1994; Dodge 1986; Fraser et al. 2011; Orobio de Castro, Verhulp and Runions 2012; Terzian et al. 2015, Van Nieuwenhuijzen et al. 2009; Ziv 2013; Ziv and Sorongon 2011). This theory has contributed to the creation of numerous childhood intervention programs with the aim of improving children's cognitive-social processes and, consequently, preventing aggressive behavior in adolescence (Conduct Problems Prevention Research Group 2011; Larsen and Angus 2011). In this theory, it is 
argued that there is a series of processes involved when a child experiences a social interaction, from the codification and interpretation of social signs, to the concretization of the answers (Crick and Dodge 1994).

In general, this model describes a sequence of cognitive operations related to how social data are processed (Dodge 1986). It proposes to synthesize the sequence of social information treatment, taking into account the performance of biologically determined capacities, as well as the repertoire of present and active information in this process. The steps of SIP described by the model are: (1) the coding of social cues; (2) the interpretation and mental representation of these cues; (3) the clarification or selection of a goal; (4) construction or access to the response; (5) the decision to response; and (6) the performance of the behavior. According to this model, certain deficits in the mechanisms responsible for the processing of social information end up sustaining a pattern of aggressive behavior as there is a loss in the ability to solve situations of impasse/conflict that tend to occur in the day-to-day (Crick and Dodge 1994).

Research has shown that children and adolescents who are aggressive at levels considered to be maladaptive demonstrate deficits at all steps of SIP when compared to those non-aggressive (Dodge et al. 1990; Katsurada and Sugawara 1998; Oostermeijer et al. 2016; Orobio de Castro et al. 2012; Van Rest et al. 2014). In general, they are more likely to encode negative signals in social information, assign hostile intentions to others (Calvete and Orue 2012, Fraser et al. 2005; Laible et al. 2014; Runions and Keating 2007; Van Rest et al. 2014) and generate and evaluate positively aggressive strategies to achieve their goals. On the other hand, they are less likely to generate relational goals (Adrian et al. 2010; Crick and Dodge 1996; Dodge and Rabiner 2004; McDonald and Lochman 2012; Orobio de Castro et al. 2012).

However, it can be stated, that, in general, few studies have investigated SIP patterns in adolescent offenders specifically, and that most of them selected only participants who had committed serious offenses (Oostermeijer et al. 2016; Shahinfar, Kupersmidt, and Matza 2001; Van Rest et al. 2014). Despite that, it is known that there are a number of persistent juvenile offenders whose conducts do not scale in gravity, that is, they do not have violent offenses in their trajectory. These aspects together support the argument that efforts need to be made to better understand the patterns of processing of social information, not only in adolescents with major persistent delinquency but also in those who present the minor persistent delinquency, which for some reason is not characterized by aggravation.

Considering the fact that more studies directly involving adolescent offenders are necessary to seek to clarify the relation between SIP patterns and the engagement in persistent offense conduct, as well as their relation to violent behavior, the present research is proposed. It is believed that it can contribute to the production of knowledge about the phenomenon and offer useful information on important aspects for the development of specialized interventions in the field of the judicial measures to which adolescent offenders are submitted, aiming to effectively meet their psychological needs.

\section{OBJECTIVE}

The present study aims to investigate the differences in SIP patterns that may exist among adolescents with major persistent offense trajectory, minor persistent offense 
trajectory and adolescents with no delinquent engagement, ascertaining the possible relations between SIP and the aggravation of offense conduct.

\section{METHOD}

\section{Participants}

The invitation to the participants was made with the authorization of an institution that is part of the Juvenile Justice System - a program responsible for the execution of judicial measures (in the cases of the adolescent offenders) and a social organization (in the cases of the other participants), in the city of Ribeirão Preto, SP, Brazil. This research is under development, and, so far, 40 male adolescents, divided into three groups, participated in this study. The first group (G1) consists of 14 adolescents whose offenses describe a major persistent trajectory, that is, a trajectory in which we can observe escalation of gravity, with acts of violence against the human person. The second group (G2) consists of 10 adolescents with an offender trajectory that can be categorized as a minor persistent trajectory, with offenses which do not include violence directed at people. Finally, the third group (G3), or comparison group, is formed by 16 adolescents without the presentation of a persistent offender trajectory. This configuration makes it possible to analyze SIP patterns according to the variable "violence" (G1) and with the variable "persistent delinquency" (G2). In addition, to improve the quality of this analysis, some variables are controlled: besides working only with male adolescents, all participants recruited reside in the same geographic region (same neighborhoods) and come from families with similar socioeconomic conditions. The age of the participants is between 16 and 18 years.

\section{Instruments}

\section{Characterization Questionnaire}

Developed by Dib and Bazon (Dib 2012) and perfected by Silva (2012), the Characterization Questionnaire was elaborated in clear and accessible language for adolescents, in order to obtain information about their sociodemographic characterization, with the purpose to classify economically the families of the adolescents, based on the proposals of the Brazilian Association of Research Companies (ABEP 2014).

\section{Self-Report Delinquency Interview}

This instrument is a self-report retrospective script with questions made in a personal and non-stigmatizing way concerning their possible involvement in activities that could be typified as offenses and whether they are known to the police/justice (official infractions) or not ("hidden" delinquency), in order to describe the trajectory of the offensive behavior of the adolescents over time and thus characterize their behavior pattern (Barberet et al. 2004). In the present study, this interview is used to identify adolescents whose behaviors describe persistent offense trajectories and, thus, to compose the groups according to the stipulated criteria.

\section{SIP Measure Protocol}

The protocol consists of vignettes of hypothetical social situations and a structured script for SIP assessment. Eight vignettes, that is, small hypothetical stories that 
illustrate social situations, concerning interpersonal relationships, were used. The vignettes were selected from a set available in the scientific literature, referring to empirical studies involving the evaluation of SIP in children and adolescents (Calvete and Orue 2009; Conduct Problems Prevention Research Group 2004; Dodge and Price 1994; Nas, Brugman, and Koops 2005; Orobio de Castro 2000; Orobio de Castro et al. 2005). It was semantically adapted to the sociocultural context by a pilot study. The vignettes are linked to a structured script of questions about the situations portrayed, in order to collect data regarding the different steps of the SIP model.

The structured script used in this study is the one proposed by Crick and Dodge (1994): (1) What happened in the story? (2) Why did people act like this? Do you think he/she intended to do that? (3) What would you do/say in that situation? (4) If you were in this situation, what would you like to happen? How would you like this story to end? Following these questions, the interviewer also presented examples of ways for the protagonist to deal with the situation, one involving assertive behavior, one involving aggressive behavior and one involving passive behavior. The following questions were: (a) Would you do something like that? (b) What do you think people would think about you if you acted like this? Do you think people would like you if you acted like that? (c) Do you think you could solve the problem if you acted this way? In order to investigate the emotions tied to each type of situation presented to the adolescent, the final question was "What would you feel if this situation happened to you?"

\section{Data Analysis}

The data collected with the Characterization Questionnaire and the Self-Report Delinquency Interview were used in order to meet the inclusion/exclusion criteria of the participants. Specifically the data obtained with the Self-Report Delinquency Interview, as already mentioned, allowed us to glimpse at the trajectory of the adolescent's delinquent conduct and, based on it, his behavioral pattern, considering the descriptive indexes of the level of delinquent engagement, which are: (1) age of onset of delinquent behavior, to assess the precocity of behavior. This kind of behavior could be classified according to the Brazilian Penal Code (Decree-Law no. 2,848, 1940, amended by Law 12,737, 2012); (2) number of offenses, including those that have been formalized (caught by the police and legally sanctioned) and the selfreported, in order to assess the total frequency of crime; (3) number of different types of offenses practiced, considering all types investigated with the interview, in order to assess the variety/diversity of manifest offensive behavior; and (4) existence of offenses involving direct contact with victims, implying a threat and/or use of instruments to achieve them, involving potential or actual harm to the physical and/ or psychological integrity of the victim, in order to assess the aggravation of the conduct.

On the basis of the literature of the area, it is considered that the more precocious, more frequent and more diverse the delinquent engagement is, the graver it is (Le Blanc 2003; Le Blanc and Fréchette 1989). The analysis of the indicators of diversity and aggravation helps to differentiate those adolescents with a pattern of persistent offense conduct, who constitute the major persistent group (G1), from those with a minor persistent trajectory (G2). For the constitution of the comparison 
Table 1. Social information processing (SIP) steps related to the interview questions and the elements evaluated in the answers

\begin{tabular}{lll}
\hline SIP & Question & Overall score \\
\hline (2) Interpretation & (1) Why did people act that way? & Hostile attribution \\
\hline $\begin{array}{l}\text { (3) Clarification of } \\
\text { objectives }\end{array}$ & $\begin{array}{c}\text { (2) If you were in this situation, what would } \\
\text { you like to happen? How would you like } \\
\text { this story to end? }\end{array}$ & Coordination of objectives \\
\hline (4) Answer constructing & $\begin{array}{l}\text { (3) What would you do/say if this situation } \\
\text { happened to you? }\end{array}$ & $\begin{array}{c}\text { Generating competent } \\
\text { responses }\end{array}$ \\
\hline (5) Answer selection & (4a) Would you do/say something like this? & $\begin{array}{c}\text { Selecting competent } \\
\text { responses }\end{array}$ \\
\hline & $\begin{array}{l}\text { (4b) What do you think people would think } \\
\text { about you if you acted like this? Do you } \\
\text { think people would like you if you } \\
\text { acted this way? }\end{array}$ & $\begin{array}{c}\text { Interpersonal effectiveness } \\
\text { (4c) Do you think you could solve the } \\
\text { problem if you acted this way? }\end{array}$ \\
\hline
\end{tabular}

group (G3) we applied the indicators of delinquent engagement in order to confirm that they effectively did not present a persistent offense trajectory.

The data obtained through the presentation of each of the vignettes and of the structured script for SIP patterns assessment were categorized and evaluated according to pre-established criteria, related to four of the six steps of SIP, according to elements highlighted in the literature, as summarized in Table 1, and to the emotion tied to each situation. After categorizing the adolescents' answers to all questions, the data obtained in each of the steps were analyzed separately, but also, together, serving as the basis for the composition of SIP total scores. The total score can be classified in three ways: SIP score - competent responses, referring to a SIP pattern favorable to the emission of socially adapted/competent behaviors; SIP aggressive responses, referring to a SIP pattern favorable to the emission of aggressive behaviors; SIP score - passive responses, referring to a SIP pattern favorable to the emission of passivity behaviors.

The coding of responses and generation of scores are based on the method suggested by Ziv and Sorongon (2011). In this way, it was possible to obtain the mean of the groups for each SIP step, for the emotion tied to the situation and also for the three scores analyzed (SIP score - competent responses, aggressive responses and passive responses). The groups were compared statistically in relation to the scores obtained in the SIP Measure Protocol using Kruskal-Wallis non-parametric analysis of variance. To identify the specific differences between one group and another, the statistical test used was the Mann-Whitney rank-sum test.

\section{RESULTS AND DISCUSSION}

The analysis of the data obtained through the Self-Report Delinquency Interview showed that 14 of the 40 adolescents interviewed had a major persistent offense trajectory. According to the same interview, it was verified that 10 adolescents had a 
Table 2. Means, medians and standard deviations of the scores obtained by the three groups for the social information processing (SIP) patterns related to competent, aggressive and passive responses

\begin{tabular}{|c|c|c|c|c|c|c|c|c|c|}
\hline & \multicolumn{3}{|c|}{ Group 1 (G1) } & \multicolumn{3}{|c|}{ Group 2 (G2) } & \multicolumn{3}{|c|}{ Comparison group (G3) } \\
\hline & Mean & Median & SD & Mean & Median & SD & Mean & Median & SD \\
\hline Competent & .54 & .56 & $.13^{\mathrm{c}}$ & .61 & .60 & $.12^{\mathrm{c}}$ & .82 & .68 & $.10^{\mathrm{a}, \mathrm{b}}$ \\
\hline Aggressive & .39 & .42 & $.15^{\mathrm{b}, \mathrm{c}}$ & .24 & .22 & $.12^{\mathrm{a}, \mathrm{c}}$ & .10 & .20 & $.08^{\mathrm{a}, \mathrm{b}}$ \\
\hline Passive & .27 & .24 & .14 & .37 & .38 & .15 & .25 & .29 & .15 \\
\hline
\end{tabular}

asignificant difference $(p<.05)$ between the highlighted score and the G1 score.

${ }^{b}$ Significant difference $(p<.05)$ between the highlighted score and the G2 score.

'Significant difference $(p<.05)$ between the highlighted score and the G3 score.

minor persistent offense trajectory and the other interviewees ( $n$ 16) did not have significant delinquent engagement. It is reiterated that the inclusion of the adolescents in each group took into account the data of the self-reported delinquency and not the official data of infractions.

Table 2 summarizes the data on the SIP patterns measured in the three groups and the statistical comparison of them. These data refer to total SIP scores, or SIP patterns, for "competent responses," "aggressive responses," and "passive responses."

We can see that the total SIP score differentiated the studied groups into two aspects. The first aspect concerns the SIP score for the processing pattern associated with competent responses (SIP score - competent responses). In this aspect, it was verified that G1 and G2 did not differ from each other, but both differed from G3. In other words, adolescents' groups with persistent offense trajectories (G1 and G2) had lower mean values than the group formed by adolescents with no significant delinquent engagement (G3) regarding the pattern of SIP, focusing on the adaptive/ competent responses (non-aggressive, non-passive) in situations of social interaction. The differences between G1 and G3 and G2 and G3 are highly significant $(p<.001)$. These data broaden the literature. They show that a less competent SIP pattern seems to be related to persistent offensive behavior, and not only to aggressive behavior.

In this context, it should be noted that the total SIP score also differentiated the groups regarding the SIP pattern associated with aggressive responses (SIP score aggressive responses). In this case, there is a significant difference between the data of all groups (G1 and G2, G1 and G3, G2 and G3). The group of adolescents with a major persistent offense trajectory presented a higher mean of "SIP score - aggressive response" when compared to the group of adolescents with a minor persistent offense trajectory, who presented a mean higher than G3. These differences seem to indicate that the SIP - aggressive responses pattern may actually be related to offenses involving violence.

Table 3 summarizes the data on the scores measured in the three groups for the "interpretation" step of SIP. The score measured for the SIP step "interpretation" refers to the variant "hostile attribution." Table 3 also shows the means, medians and standard deviations of each group for this variant, as well as the signaling of the statistical differences of the groups in this question.

It is possible to note that there are no significant differences between G1 and G2 regarding "hostile attribution" in the interpretation of social cues step; the adolescents of both groups have higher means than those of G3, in all sets of hypothetical 
Table 3. Means, medians and standard deviations of the scores obtained by the three groups for the social information processing (SIP) step: interpretation of social cues regarding hostile attribution

\begin{tabular}{|c|c|c|c|c|c|c|c|c|c|}
\hline & \multicolumn{3}{|c|}{ Group 1 (G1) } & \multicolumn{3}{|c|}{ Group 2 (G2) } & \multicolumn{3}{|c|}{ Comparison group (G3) } \\
\hline & Mean & Median & SD & Mean & Median & SD & Mean & Median & SD \\
\hline Hostile attribution & 5.14 & 5.00 & $1.56^{\mathrm{c}}$ & 4.30 & 4.50 & $1.95^{\mathrm{c}}$ & 1.88 & 2.00 & $1.31^{\mathrm{a}, \mathrm{b}}$ \\
\hline
\end{tabular}

${ }^{\text {a }}$ Significant difference $(p<.05)$ between the highlighted score and the G1 score.

${ }^{\text {b }}$ Significant difference $(p<.05)$ between the highlighted score and the G2 score.

'Significant difference $(p<.05)$ between the highlighted score and the G3 score.

Table 4. Means, medians and standard deviations of the scores obtained by the three groups for the social information processing (SIP) step: construction of the response for aggressive, passive and assertive responses

\begin{tabular}{|c|c|c|c|c|c|c|c|c|c|}
\hline & \multicolumn{3}{|c|}{ Group 1 (G1) } & \multicolumn{3}{|c|}{ Group 2 (G2) } & \multicolumn{3}{|c|}{ Comparison group (G3) } \\
\hline & Mean & Median & SD & Mean & Median & SD & Mean & Median & SD \\
\hline Aggressive & 2.71 & 3.00 & $1.38^{\mathrm{b}, \mathrm{c}}$ & .80 & 1.00 & $.63^{\mathrm{a}}$ & .44 & .00 & $.73^{\mathrm{a}, \mathrm{b}}$ \\
\hline Passive & 1.79 & 1.50 & $1.31^{\mathrm{c}}$ & 2.50 & 3.00 & $1.72^{\mathrm{C}}$ & .88 & 1.00 & $.96^{\mathrm{a}, \mathrm{b}}$ \\
\hline Assertive & 3.36 & 3.50 & $1.15^{\mathrm{c}}$ & 4.60 & 4.50 & $1.71^{\mathrm{c}}$ & 6.69 & 6.50 & $1.08^{\mathrm{a}, \mathrm{b}}$ \\
\hline
\end{tabular}

${ }^{a}$ Significant difference $(p<.05)$ between the highlighted score and the G1 score.

${ }^{\text {b }}$ Significant difference $(p<.05)$ between the highlighted score and the G2 score.

'Significant difference $(p<.05)$ between the highlighted score and the G3 score.

situations evaluated. From these data, it can be verified that adolescents with significant delinquent engagement, even with distinct trajectories regarding aggravation, tend to attribute hostile intention to the other in ambiguous social situations. These data corroborate findings from a number of studies about the relation between the attribution of hostility to the other and aggressive behavior (Calvete and Orue 2012, Fraser et al. 2005, Laible et al. 2014, Nelson and Perry 2015; Runions and Keating 2007).

The data presented here, however, amplify the understanding of this phenomenon, as they also indicate that this characteristic seems to be related to the development of the offensive behavior, in general, independently of the offense's conduct integrating or not crimes with violence against the person. Indications about this relation were pointed out by Van Rest et al. (2014). The authors of this study found relations between attributing hostility to each other and violating rules; however, they had not directly compared adolescents with persistent major and minor trajectories. The indifferent comparison of offenders and non-offenders, common to most studies in the field, impairs the endeavors to acknowledge independent relations between SIP and delinquency patterns.

Table 4, on the other hand, presents the data of the scores measured in the three groups, regarding the SIP step "construction of the response", for the "aggressive responses," "passive responses" and "assertive responses" variants. Table 4 shows the significant differences between the scores of each group for each variant.

On the SIP step "construction of the response" it is possible to verify, based on the data synthesized in Table 4, that the scores indicate significant differences between the groups. The "construction of the response" score for the "aggressive responses" 
Table 5. Means, medians and standard deviations of the scores obtained by the three groups for the social information processing (SIP) step: "clarification of objectives" for instrumental, relational and coordinated objectives

\begin{tabular}{|c|c|c|c|c|c|c|c|c|c|}
\hline & \multicolumn{3}{|c|}{ Group 1 (G1) } & \multicolumn{3}{|c|}{ Group 2 (G2) } & \multicolumn{3}{|c|}{ Comparison group (G3) } \\
\hline & Mean & Median & SD & Mean & Median & SD & Mean & Median & SD \\
\hline Instrumental & 4.07 & 3.50 & $2.16^{c}$ & 2.60 & 3.00 & $1.35^{c}$ & .69 & .00 & $1.14^{\mathrm{a}, \mathrm{b}}$ \\
\hline Relational & .57 & .00 & $1.09^{b}$ & 1.60 & 1.50 & $1.58^{\mathrm{a}, \mathrm{c}}$ & .25 & .00 & $.58^{b}$ \\
\hline Coordinated & 3.14 & 3.00 & $1.96^{c}$ & 3.70 & 4.00 & $.95^{c}$ & 7.00 & 7.00 & $1.15^{\mathrm{a}, \mathrm{b}}$ \\
\hline
\end{tabular}

asignificant difference $(p<.05)$ between the highlighted score and the G1 score.

${ }^{b}$ Significant difference $(p<.05)$ between the highlighted score and the $\mathrm{G} 2$ score.

'Significant difference $(p<.05)$ between the highlighted score and the G3 score.

variant differentiates G1 from G2 and G3, indicating that adolescents with a major persistent trajectory construct/list more aggressive types of responses through different social interaction situations. The G2 mean scores for the "aggressive responses" construct, although smaller than those for G1, are greater than those for G3. In other words, it is observed that for this step of SIP, the recurrence of aggressive responses increases with the adolescents' level of involvement in violent delinquency. It can be considered that the variable "construction of the responses - aggressive responses" increases in frequency as the aggravation of the delinquent conduct of the adolescent also increases.

The overall score for "construction of the responses" of the "assertive responses" and "passive responses" variants, however, differ only in G3. Similar to the data found for the "SIP score - competent responses," these data suggest that adolescents with significant delinquent involvement (persistent offense trajectory) construct/list fewer competent responses than adolescents of the same age without delinquent involvement.

As for the SIP step "clarification of objectives," Table 5 summarizes the data on the scores of the three groups for the "instrumental objectives," "relational objectives" and "coordinated objectives" variants. This table shows the means, medians and standard deviations of the groups for each variant of this step, as well as the significant differences.

Regarding the SIP step - "clarification of objectives," it should be noted that the responses provided by adolescents were categorized into three classes: instrumental, relational or coordinated. In Table 5 it is possible to note that many significant differences were found between the means of the groups. These data corroborate research in the area that indicates that this is the central step for SIP (Adrian et al. 2010; McDonald and Lochman 2012). It must be noted that there was no significant difference in the selection of "instrumental objectives" between G1 and G2, although both differed from G3, since they presented more objectives of this type. These preliminary data contradict results from the literature about the relation between "instrumental objectives" and violent behavior (Adrian et al. 2010; Dodge and Rabiner 2004; McDonald and Lochman 2012), since they indicate a relation between "instrumental objectives" and persistent offense trajectory in general.

On the other hand, it was observed that G2 adolescents presented more "relational objectives" than those of G1 and G3. This configuration seems to indicate that in 
Table 6. Means, medians and standard deviations of the scores obtained by the three groups for the social information processing (SIP) step: response selection for aggressive, passive and assertive responses

\begin{tabular}{|c|c|c|c|c|c|c|c|c|c|}
\hline & \multicolumn{3}{|c|}{ Group 1 (G1) } & \multicolumn{3}{|c|}{ Group 2 (G2) } & \multicolumn{3}{|c|}{ Comparison group (G3) } \\
\hline & Mean & Median & SD & Mean & Median & SD & Mean & Median & SD \\
\hline Aggressive & 3.29 & 3.50 & $1.54^{b, c}$ & 1.20 & 1.00 & $.79^{a, c}$ & .56 & .00 & $.89^{a, b}$ \\
\hline Passive & 3.07 & 3.00 & 1.86 & 4.20 & 4.50 & 1.81 & 3.38 & 3.00 & 1.82 \\
\hline Assertive & 5.43 & 6.00 & $1.70^{\mathrm{c}}$ & 6.30 & 6.50 & 1.70 & 7.13 & 7.00 & $.89^{a}$ \\
\hline
\end{tabular}

${ }^{a}$ Significant difference $(p<.05)$ between the highlighted score and the G1 score.

${ }^{\mathrm{b}}$ Significant difference $(p<.05)$ between the highlighted score and the G2 score.

'Significant difference $(p<.05)$ between the highlighted score and the G3 score.

certain situations of social interaction the group composed of adolescents with a minor persistent offense trajectory presents SIP associated with passive behavior, differently from the adolescents with a major persistent offender trajectory and those without significant delinquent engagement.

Table 6 summarizes the data on the scores measured in the three groups for the SIP step "response selection" for the "aggressive responses," "passive responses" and "assertive responses" variants. In addition, Table 6 presents the statistical comparison of the groups.

The "response selection" step has three components as highlighted in the Method section. After presenting examples of aggressive, passive, and assertive responses to hypothetical situations presented to the participants, questions were asked to investigate the beliefs of adolescents regarding the efficacy of each. The results obtained through the first question related to this step (Would you do something like this?) indicated that G1 differed from the other groups in the "selection of aggressive responses," which can be seen in Table 6. The score for the "selection of aggressive responses" indicates a relation similar to that verified in the "construction of the response" step, since G1 presents a mean greater than G2 for the "selection of aggressive responses" and G2 presents a mean greater than G3.

Regarding the "response selection - interpersonal efficacy" step, Table 7 presents the data regarding the scores of the three groups for the "aggressive responses," "passive responses" and "assertive responses" and "indifference responses" variants. The means and the medians of the groups for each variant and the standard deviations are shown in this table. In addition, the significant differences between the groups are highlighted.

In Table 7, which illustrates the means of each group for interpersonal efficacy, it is possible to note significant differences between G1 and G2 and G3; however, G1 does not differ from G2. "Aggressive responses" were equally valued for interpersonal efficacy by G1 and G2. Another aspect that differentiated these groups (G1 and G2) from adolescents without significant delinquent engagement (G3) was the "indifferent" answers to the question about this step: "What do you think people would think about you if you acted like this?" In these cases, adolescents with persistent offense involvement demonstrated difficulty in answering the question, sometimes saying that they did not know how to answer it, sometimes reporting that they did not care about what others would think. This class of responses would not be 
Table 7. Means, medians and standard deviations of the scores obtained by the three groups for the social information processing (SIP) step: response selection interpersonal efficacy for aggressive, passive and assertive responses and for indifference responses

\begin{tabular}{|c|c|c|c|c|c|c|c|c|c|}
\hline & \multicolumn{3}{|c|}{ Group 1 (G1) } & \multicolumn{3}{|c|}{ Group 2 (G2) } & \multicolumn{3}{|c|}{ Comparison group (G3) } \\
\hline & Mean & Median & SD & Mean & Median & SD & Mean & Median & SD \\
\hline Aggressive & 1.36 & 1.50 & $1.22^{c}$ & 1.20 & 1.00 & $1.23^{c}$ & .38 & .00 & $.81^{\mathrm{a}, \mathrm{b}}$ \\
\hline Passive & 2.57 & 3.00 & 1.40 & 2.50 & 2.50 & 1.84 & 3.13 & 4.00 & 2.00 \\
\hline Asssertive & 5.29 & 5.50 & 2.23 & 6.00 & 6.50 & 1.89 & 6.81 & 7.00 & 1.05 \\
\hline Indifference & 3.71 & 1.00 & $4.55^{c}$ & 1.80 & .50 & $2.39^{c}$ & .44 & .00 & $1.50^{\mathrm{a}, \mathrm{b}}$ \\
\hline
\end{tabular}

asignificant difference $(p<.05)$ between the highlighted score and the G1 score.

${ }^{\mathrm{b}}$ Significant difference $(p<.05)$ between the highlighted score and the G2 score.

'Significant difference $(p<.05)$ between the highlighted score and the G3 score.

Table 8. Means, medians and standard deviations of the scores obtained by the three groups for the social information processing (SIP) step: response selection instrumental effectiveness for aggressive, passive and assertive responses

\begin{tabular}{|c|c|c|c|c|c|c|c|c|c|}
\hline & \multicolumn{3}{|c|}{ Group 1 (G1) } & \multicolumn{3}{|c|}{ Group 2 (G2) } & \multicolumn{3}{|c|}{ Comparison group (G3) } \\
\hline & Mean & Median & SD & Mean & Median & SD & Mean & Median & SD \\
\hline Aggressive & 2.21 & 2.00 & $1.72^{c}$ & 1.40 & 1.00 & 2.12 & .69 & .00 & $.95^{\mathrm{a}}$ \\
\hline Passive & 2.93 & 3.00 & 1.73 & 4.10 & 4.50 & 1.79 & 2.69 & 2.50 & 2.02 \\
\hline Asssertive & 6.36 & 6.50 & $1.22^{c}$ & 6.50 & 6.50 & 1.27 & 7.31 & 7.50 & $.87^{\mathrm{a}}$ \\
\hline
\end{tabular}

a Significant difference $(p<.05)$ between the highlighted score and the G1 score.

${ }^{\mathrm{b}}$ Significant difference $(p<.05)$ between the highlighted score and the G2 score.

'Significant difference $(p<.05)$ between the highlighted score and the G3 score.

contemplated if the SIP were measured through a questionnaire, as it is commonly done; so these data may represent a novelty in research, although we have some important theories in the area, which point to the conception that young offenders have deficits in their cognitive development and in perspective role taking (Le Blanc, Vallières, and McDuff 1993).

Table 8 presents the data about the scores of the three groups for the SIP step "response selection - instrumental effectiveness" for the "aggressive responses," "passive responses" and "assertive responses" variants. In addition, Table 8 presents the statistical comparison of the means obtained by the three groups.

In Table 8 it is possible to observe few differences between the groups. Only G1 and G3 differed in the instrumental effectiveness scores of "aggressive responses" and "assertive responses." It must be pointed out that, until now, the differences between the groups, especially between groups of adolescents with persistent - major and minor - trajectories, are more strongly concentrated in the initial steps of SIP, and become less significant in the final steps of SIP.

As for the variable "emotion" tied to each situation, Table 9 presents the means and medians of each variant ("anger," "sadness," "fear" and "indifference") and also the standard deviations and statistical differences between each. 
Table 9. Means, medians and standard deviations of the scores obtained by the three groups for the emotions of anger, sadness and fear, and absence of emotion

\begin{tabular}{|c|c|c|c|c|c|c|c|c|c|}
\hline & \multicolumn{3}{|c|}{ Group 1 (G1) } & \multicolumn{3}{|c|}{ Group 2 (G2) } & \multicolumn{3}{|c|}{ Comparison group (G3) } \\
\hline & Mean & Median & SD & Mean & Median & SD & Mean & Median & SD \\
\hline Anger & 5.00 & 5.00 & $1.18^{b, c}$ & 3.00 & 3.00 & $1.25^{\mathrm{a}}$ & 3.31 & 3.00 & $1.14^{\mathrm{a}}$ \\
\hline Sadness & .64 & .00 & $.84^{c}$ & 1.40 & 1.00 & 1.35 & 1.88 & 2.00 & $.96^{\mathrm{a}}$ \\
\hline Fear & .21 & .00 & $.43^{b, c}$ & .60 & 1.00 & $.52^{\mathrm{a}}$ & .75 & 1.00 & $.45^{\mathrm{a}}$ \\
\hline Indifference & 1.71 & 1.00 & 1.49 & 2.90 & 3.00 & 2.13 & 2.13 & 2.00 & 1.50 \\
\hline
\end{tabular}

${ }^{a}$ Significant difference $(p<.05)$ between the highlighted score and the G1 score.

${ }^{\mathrm{b}}$ Significant difference $(p<.05)$ between the highlighted score and the $\mathrm{G} 2$ score.

'Significant difference $(p<.05)$ between the highlighted score and the G3 score.

As for the resentful emotions coupled to each situation investigated in the vignettes, as can be seen in the synthesis of results presented in Table 9, G2 did not differ significantly from G3. These data may suggest that there are no differences regarding the resentful emotions among adolescents presenting a minor persistent delinquency and adolescents without delinquent engagement. G1, in turn, had general "anger" scores higher than G2 and G3. Also, the score for "fear" was lower in G1 than in the others. These scores indicate that the type of resentful emotion in social interaction seems to be an important factor of SIP, and also seems to be associated with the pattern of offensive behavior, whether characterized by violence.

\section{FINAL CONSIDERATIONS}

In general, it is possible to notice through the results that the studied groups differed in several aspects in SIP. Some peculiar characteristics of each trajectory of offensive conduct allow us to even glimpse at SIP patterns for each group. It was observed, for example, that adolescents with a major persistent offense trajectory and minor persistent offense trajectory interpret social cues equally, tending to attribute more hostile intentions to the other. Both also have a SIP pattern that is poorly associated with socially competent behavior. However, the group of adolescents with a major persistent offense trajectory presents a SIP pattern more associated with the emission of aggressive behaviors. This pattern, although also present in the group of adolescents with a minor persistent offense trajectory, is more evident for those who reported committing offenses with the use of violence against people. Adolescents with a major persistent offense trajectory also feel more anger and less fear when they interpret an ambiguous social situation which can effectively increase the chance of aggressive responses.

For Dodge and Pettit (2003), different patterns of SIP can exist because children/ adolescents accumulate social knowledge through early experiences that contribute to the formation of beliefs, schemes, and scripts used to establish and maintain relationships. This accumulated social knowledge, along with biological dispositions (such as impulsivity, tendency to addiction, attention deficits, and difficult temperament), as well as environmental influences/life experience (such as poverty and violence, harsh parental discipline and rejection by parents and/or by peers), 
influence how children codify environmental cues, interpret the intentions of others, set goals in social relationships, and develop behavioral repertoires. For the authors, the biological dispositions of the child, the sociocultural context, and life experiences are mutually influenced by each other through time. SIP patterns, therefore, are mediators of these experiences of the child's life and later behavior.

In this sense, according to the sociocognitive model, the behavior pattern of an individual is not understood as a direct result of external social events experienced by him or by his temperament/constitutional predispositions. Despite playing very important roles, these external and internal factors are understood as events and predispositions influenced by the cognitive resources of the developing child/adolescent. Cognitive aspects develop and become characterized by increasingly individualized and stable patterns, but, even so, potentially modifiable through direct intervention. Therefore, because they are stable factors and underlying organizers of behavior, interventions in cognitive mediators can result in relatively stable patterns of behavior (Eron 1987 as cited in Guerra and Slaby 1990).

In this way, the results obtained in the present study support the elaboration of interventions that act directly on cognitive factors which might be underlying both major and minor persistent offense trajectories. The differences found among the SIP patterns observed for each group point to the importance of these factors in the behavioral trajectory of adolescents. The data obtained in this study revealed significant differences in the SIP of juvenile offenders with different delinquency trajectories, indicating that cognitive interventions should consider that adolescent offenders present peculiarities in their SIP and therefore such interventions should prioritize distinct aspects for each behavioral trajectory.

The fact that both groups of adolescent offenders present higher averages of hostile attribution, for example, may indicate that cognitive interventions in this sense are necessary for adolescent offenders in general. Likewise, the results indicate that juvenile offenders, regardless of their offenses trajectory, would benefit from interventions aimed at the development of social skills, since both groups presented a SIP pattern less associated with socially competent behavior than adolescents of the population. However, the fact that adolescents who committed crimes against the person show differences from the other groups concerning emotions tied to each type of situation presented suggests that cognitive interventions related to the management of emotions, specifically anger, are more necessary to this group than to others.

The group of adolescents with a major persistent offenses trajectory presents a SIP pattern associated with the emission of aggressive behaviors. This pattern, although also present in the group of adolescents with a minor persistent offenses trajectory, is more evident for those who reported committing offenses with the use of violence. Thus, it can be presumed, for example, that interventions aimed at changing beliefs and values regarding the use of aggression and revenge goals are important to both groups, but especially to the group of adolescents with a major persistent offender trajectory. Many intervention programs have been developed with the purpose of modifying SIP patterns and have shown important results regarding the reduction of aggressive behavior. Most of these programs are preventive (Conduct Problems Prevention Research Group 2011; Durlak et al. 2011; Jones, Brown, and Aber 2011). 
The different SIP patterns observed in each group also endorse the importance of cognitive interventions that can be performed with adolescents in their current lifetime, as suggested by some intervention programs that were effectively performed with violent adolescents (Fraser et al. 2005; Larsen and Angus 2011). Therefore, the results of this study indicate, although in a preliminary way, directions for the planning of cognitive interventions to be carried out with adolescents who are in conflict with the law.

\section{References}

ABEP. 2014. "Associação Brasileira de Empresas de Pesquisa. Critério de Classificação Econômica, Brasil." Retrieved April 13, 2015 (http://www.abep.org).

Adrian, Molly, Aaron R. Lyon, Rosalind Oti, and Jennifer Tininenko. 2010. "Developmental Foundations and Clinical Applications of Social Information Processing: A Review." Marriage and Family Review 46:327-45.

Barberet, Rosemary, Benjamin Bowling, Josine Junger-Tas, Cristina Rechea-Alberola, John van Kesteren, and Andrew Zuruwan. 2004. Self-Reported Juvenile Delinquency in England and Wales, The Netherlands and Spain. Helsinki: Heuni.

Bazon, Marina R., André V. Komatsu, Ivana R. Panosso, and Ruth Estevão. 2011. "Adolescentes em Conflito com a Lei, Padrões de Comportamento Infracional e Tragetória da Conduta Delituosa: Um Modelo Explicativo na Perspectiva Desenvolvimental." Revista Brasileira Adolescência e Conflitualidade 5:59-87.

Calvete, Esther and Izaskun Orue. 2009. "Evaluación del Procesamiento de la Información Social em Adolescentes Españoles y su Associón com la Conducta Agresiva.” Behavioral Psychology/Psicologia Conductual 17(3):523-42.

Calvete, Esther and Izaskun Orue. 2012. "Social Information Processing as a Mediator Between Cognitive Schemas and Aggressive Behavior in Adolescents." Journal of Abnormal Child Psychology 40 (1):105-17.

Conduct Problems Prevention Research Group. 2004. "The Effects of the Fast Track Program on Serious Problem Outcomes at the End of Elementary School." Journal of Clinical Child and Adolescent Psychology 33:650-61.

Conduct Problems Prevention Research Group. 2011. "The Effects of the Fast Track Preventive Intervention on the Development of Conduct Disorder across Childhood." Child Development 82 (1):331-45.

Crick, Nicki R. and Kenneth A. Dodge. 1994. "A Review and Reformulation of Social Information-Processing Mechanisms in Children's Social Adjustment." Psychological Bulletin 115: 74-101.

Crick, Nicki R. and Kenneth A. Dodge. 1996. "Social Information-Processing Mechanisms in Reactive and Proactive Aggression.” Child Development 67:993-1002.

Dib, Marina A. 2012. "A regulação da conduta delituosa pela família: um estudo comparativo entre adolescentes judiciarizados e não judiciarizados no contexto brasileiro." Masters dissertation, Universidade de São Paulo, Ribeirão Preto, SP.

Dodge, Kenneth A. 1986. "A Social Information Processing Model of Social Competence in Children." Pp. 77-125 in Minnesota Symposium in Child Psychology. Cognitive Perspectives in Children's Social and Behavioral Development, Vol. 18, edited by M. Perlmutter. Hillsdale, NJ: Erlbaum.

Dodge, Kenneth A. and Gregory S. Pettit. 2003. "A Biopsychosocial Model of the Development of Chronic Conduct Problems in Adolescence." Developmental Psychology 39:349-71.

Dodge, Kenneth A. and Joseph M. Price. 1994. "On the Relation between Social Information Processing and Socially Competent Behavior in Early School-Aged Children." Child Development 65 (5):1385-97.

Dodge, Kenneth A., Joseph M. Price, Joanne Bachorowski, and Joseph M. Newman. 1990. "Hostile Attributional Biases in Severely Aggressive Adolescents." Journal of Abnormal Psychology 99:385-92. 
Dodge, Kenneth A. and David L. Rabiner. 2004. "Returning to Roots: On Social Information Processing and Moral Development." Child Development 75(4):1003-8.

Durlak, Joseph A., Roger P. Weissberg, Allison B. Dymnicki, Rebecca D. Taylor, and Kriston B. Schellinger. 2011. "The Impact of Enhancing Students' Social and Emotional Learning: A Meta-Analysis of SchoolBased Universal Interventions.” Child Development 82(1):405-32.

Fraser, Mark W., Maeda Galinsky, Paul Smokowski, Steven Day, Mary Terzian, Roderick Rose, and Shenyang Guo. 2005. "Social Information-Processing Skills Training to Promote Social Competence and Prevent Aggressive Behavior in the Third Grades." Journal of Consulting and Clinical Psychology 73:1045-55.

Fraser, Mark W., Shenyang Guo, Alan R. Ellis, Aaron M. Thompson, Traci L. Wike, and Jilan Li. 2011. "Outcome Studies of Social, Behavioral, and Educational Interventions: Emerging Issues and Challenges." Research on Social Work Practice 21:619-35.

Fréchette, Marcel and Marc LeBlanc. 1987. Délinquances et Delinquants. Montreal: Gaëtan Morin Éditeur Itée.

Guerra, Nancy G. and Ronald G. Slaby. 1990. "Cognitive Mediators of Aggression in Adolescent Offenders: 2. Intervention.” Developmental Psychology 26:269-77.

Jones, Stephanie M., Joshua L. Brown, and J. Lawrence Aber. 2011. “Two-Year Impacts of a Universal School-Based Social-Emotional and Literacy Intervention: An Experiment in Translational Developmental Research.” Child Development 82(2):533-54.

Katsurada, Emiko and Alan I. Sugawara. 1998. "The Relationship between Hostile Attributional Bias and Aggressive Behavior in Preschoolers." Early Childhood Research Quarterly 13 (4):623-36.

Komatsu, André V. 2014. "Comportamentos antissociais em adolescentes do sexo masculino: um estudo exploratório na cidade de Ribeirão Preto - SP.” Masters dissertation, Universidade de São Paulo, Ribeirão Preto, SP.

Laible, Deborah, Gustavo Carlo, Tia Panfile Murphy, Mairin Augustine, and Scott C. Roesch. 2014. "Predicting Children's Prosocial and Co-operative Behavior from their Temperamental Profiles: A Person-Centered Approach.” Social Development 23(4):734-52.

Larsen, Reed W. and Rachel M. Angus. 2011. "Adolescents' Development of Skills for Agency in Youth Programs: Learning to Think Strategically.” Child Development 82(1):277-94.

Le Blanc, Marc. 2003. "Trajetórias de Delinquencia Comum, Transitória e Persistente: Uma estratégia de Prevenção Diferencial.” Pp. 31-80 in Comportamento Anti-Social: Escola e Família, edited by I. Alberto. Coimbra: Centro de Psicopedagogia da Universidade de Coimbra.

Le Blanc, Marc. 2010. "Un Paradigme Développemental Pour la Criminologie: Développement et Autorégulation de la Conduite Déviante.” Criminologie 43(2):401-28.

Le Blanc, Marc and Marcel Fréchette. 1989. Male Criminal Activity, from Childhood through Youth: Multilevel and Developmental Perspectives. New York: Springer-Verlag.

Le Blanc, Marc, Évelyne Vallières, and Pierre McDuff. 1993. “The Prediction of Males' Adolescent and Adult Offending from School Experience." Canadian Journal of Criminology 35:459-78.

Lei n. 12.737, de 30 de novembro de 2012. 2012. Provides for the criminalization of computer crimes; Amends Decree-Law No. 2,848, of 7 December 1940 - Penal Code; And makes other arrangements. Brasilia DF. Retrieved on April 13, 2013 (http://www.planalto.gov.br/ccivil_03/_Ato2011-2014/2012/ Lei/L12737.htm).

Loeber, Rolf, Kate Keenan, and Quanwu Zhang. 1997. "Boys' Experimentation and Persistence in Developmental Pathways Toward Serious Delinquency." Journal of Child and Family Studies 6(3): 321-57.

McDonald, Kristina L. and John E. Lochman. 2012. "Predictors and Outcomes Associated with Trajectories of Revenge Goals from Fourth Grade Through Seventh Grade." Journal of Abnormal Child Psychology 40:225-36.

Mun, Eun Y., Michael Windle, and Lisa M. Schainker. 2008. “A Model-Based Cluster Analysis Approach to Adolescent Problem Behaviors and Young Adult Outcomes." Development and Psychopathology 20(1):291-318.

Nas, Coralijn N., Daniel Brugman, and W. Koops. 2005. "Effects of the EQUIP Programme on the Moral Judgement, Cognitive Distortions, and Social Skills and Juvenile Delinquents." Psychology, Crime and Law 11(4):421-34. 
Nelson, Jackie A. and Nicole B. Perry. 2015. "Emotional Reactivity, Self-Control and Children's Hostile Attributions Over Middle Childhood." Cognition and Emotion 29(4):592-603.

Oostermeijer, S., M. Nieuwenhuijzen, P. M. Van de Ven, A. Popma, and L. M. C. Jansen. 2016. "Social Information Processing Problems Related to Reactive and Proactive Aggression of Adolescents in Residential Treatment." Personality and Individual Differences 90:54-60.

Orobio de Castro, Bram. 2000. Social Information Processing and Emotion in Antisocial Boys. Amsterdam: PI Research.

Orobio de Castro, Bram, Welmoet Merk, Willem Koops, Jan W. Veerman, and Jopp D. Bosch. 2005. "Emotions in Social Information Processing and Their Relations with Reactive and Proactive Aggression in Referred Aggressive Boys." Journal of Clinical Child and Adolescent Psychology 34(1):105-16.

Orobio de Castro, Bram, Esmée E. Verhulp, and Kevin Runions. 2012. "Rage and Revenge: Highly Aggressive Boys' Explanations For Their Responses to Ambiguous Provocation." European Journal of Developmental Psychology 9(3):331-50.

Panosso, Ivana R. 2008. "Comparação da adaptação pessoal de adolescentes judiciarizados e nãojudiciarizados: a aplicação do Inventário de Personalidade de Jesness e de Eysenck e de Humores Depressivos de Beck.” Masters dissertation, Universidade de São Paulo, Ribeirão Preto, SP.

Runions, Kevin C. and Daniel P. Keating. 2007. "Young Children's Social Information Processing: Family Antecedents and Behavioral Correlates." Developmental Psychology 43(4):838-49.

Shahinfar, Ariana, Janis B. Kupersmidt, and Louis S. Matza. 2001. "The Relation Between Exposure to Violence and Social Information Processing Among Incarcerated Adolescents." Journal of Abnormal Psychology 110:136-41.

Silva, Jorge L. 2012. "A Regulação da Conduta Delituosa pela Escola: Um Estudo Comparativo entre Adolescentes Judiciarizados e Não-Judiciarizados no Contexto Brasileiro.” Masters dissertation, Universidade de São Paulo, Ribeirão Preto, SP.

Terzian, Mary A., Jilan Li, Mark W. Fraser, Steven H. Day, and Roderick A. Rose. 2015. "Social Information-Processing Skills and Aggression: A Quasi-Experimental Trial of the Making Choices and Making Choices Plus Programs." Research on Social Work Practice 25(3):358-69.

Van Nieuwenhuijzen, Maroesjka, Bram Orobio de Castro, L. Wijnroks, Adri Vermeer, and Walter Matthys. 2009. "Social Problem-Solving and Mild Intellectual Disabilities: Relations with Externalizing Behavior and Therapeutic Context." American Journal on Intellectual and Developmental Disabilities 114(1):42-51.

Van Rest, Maaike M., Irene van Borkhoven, Maroesjka Van Nieuwenhujizen, Petri J. C. M. Embregts, Aart Vriens, and Walter Matthys. 2014. "Developing a New Assessment Procedure of Social Information Processing in Adolescents within Secure Residential Care." Research in Developmental Disabilities 35:1402-11.

Ziv, Yair. 2013. "Social Information Processing Patterns, Social Skills, and School Readiness in Preschool Children." Journal of Experimental Child Psychology 114(2):306-20.

Ziv, Yair and Alberto Sorongon. 2011. "Social Information Processing in Preschool Children: Relations to Sociodemographic Risk and Problem Behavior." Journal of Experimental Child Psychology 109 (4):412-29.

\section{TRANSLATED ABSTRACTS}

\section{Sinopsis}

El presente estudio investigó las diferencias en los patrones de procesamiento de información social (SIP) entre adolescentes con dos trayectorias de delincuentes: Grupo 1 (G1) compuesto por adolescentes con una trayectoria de delitos persistentes mayores, que incluye actos ilegales considerados violentos; Grupo 2 (G2) compuesto por individuos con una trayectoria de delitos menores persistentes, en los que no hay escalada de la gravedad de los delitos; y el Grupo de comparación (G3) con adolescentes sin participación en delitos. El SIP (patrones de procesamiento de información social) es uno de los modelos teóricos más evocados para estudiar y explicar el comportamiento violento en niños / adolescentes, en lo 
que respecta a los procesos psicológicos que subyacen al comportamiento, específicamente a la naturaleza cognitiva. Los participantes respondieron una entrevista de autoinforme sobre delincuencia y un Protocolo de Medida SIP. Los resultados mostraron diferencias entre los grupos de delincuentes (G1 y G2) y el Grupo de comparación (G3) en el patrón SIP relacionados con las respuestas competentes. G1 y G2 revelaron un patrón SIP mal asociado con un comportamiento socialmente competente. Sin embargo, G1 presentó un patrón SIP más asociado con la emisión de comportamientos agresivos. Este patrón, aunque también presente en G2, es más evidente para aquellos adolescentes que informaron haber cometido delitos con el uso de la violencia contra las personas.

Palabras clave: delincuencia juvenil; procesamiento de información social; cognición social; agravamiento de conducta

\section{Résumé}

Le présente étude a examiné les différences de modèles de traitement de l'information sociale chez les adolescents ayant deux parcours de délinquance: le groupe 1 (G1) composé d'adolescents présentant un parcours d'infractions persistantes majeures, ce qui comprend les actes illégaux considérés comme violents; Groupe 2 (G2) composé d'individus ayant un parcours d'infractions mineures persistantes, dans laquelle il n'y a pas d'aggravation du niveau des infractions; et le Groupe de comparaison (G3) avec des adolescents sans implication dans des infractions. Le SIP (traitement de l'information sociale) est l'un des modèles théoriques les plus largement évoqués pour étudier et expliquer les comportements violents chez les enfants / adolescents, en considérant les processus psychologiques qui sous-tendent le comportement, en particulier la nature cognitive. Les participants ont répondu à un entretien d'autoévaluation de la délinquance et à un protocole de mesure du SIP. Les résultats ont montré des différences entre les groupes de délinquants (G1 et G2) et le groupe de comparaison (G3) sur le profil SIP lié aux réponses compétentes. G1 et G2 ont révélé un profil SIP mal associé à un comportement socialement compétent. Cependant, G1 présentait un profil SIP plus associé à l'émission de comportements agressifs. Ce schéma, bien que présent également dans le G2, est plus évident pour les adolescents qui ont déclaré avoir commis des crimes avec recours à la violence contre les personnes.

Mots-clés: délinquance juvénile; traitement social de l'information; cognition sociale; aggravation du comportement

\section{摘要 \\ 本研究调查了两项犯罪轨迹的青少年社会信息处理模式差异 : 第一 (G1) 由具有重 大、持续暴力行为犯罪迹象的青少年组成;第2组 (G2) 由具有轻微持续犯罪轨迹的 个人组成, 其中不存在罪行严重性升高;和比较组 (G3) 没有参与犯罪的青少年组。 SIP是研究和解释儿童/青少年暴力行为的最广泛引用的理论模式之一, 涉及行为基 础的心理过程, 特别是认知性质。参与者回答了自我报告犯罪访谈和SIP措施协议。 结果显示, 犯罪组 (G1和G2) 与对照组 (G3) 之间的差异在SIP模式与回应能力有 关。G1和G2的对照发现SIP模式与社会行为有关。G1显示SIP模式与排斥侵略行为 关系密切, 这种关联虽然也出现在G2中, 但对于报告中对他人具有暴力侵害特性的 青少年来说更为明显。}




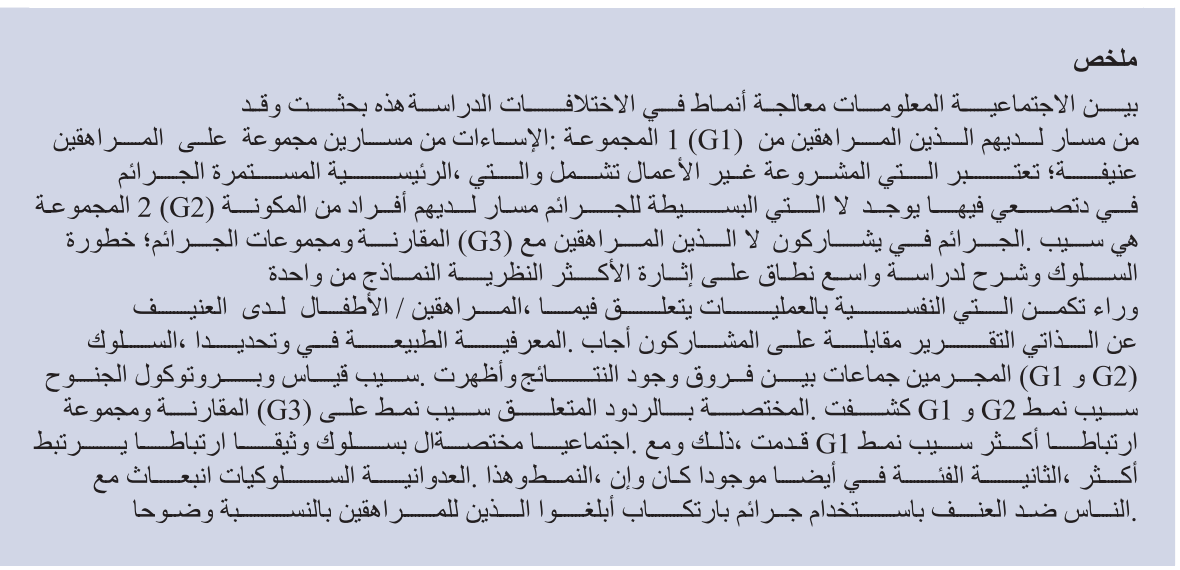

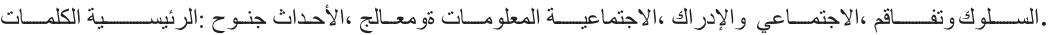

Marina Rezende Bazon is associated professor in the Department of Psychology at the Faculdade de Filosofia, Ciências e Letras de Ribeirão Preto, University of São Paulo (USP-RP). She is a graduate in psychology from the University of São Paulo (1991), Master in Science in psychoéducation from the University of Montreal/Canada (1995) and Doctor in psychology from the University of São Paulo (1999). She is an Associated Member of the Brazilian Society of Psychology, Member of the International Society of Criminology and a Coordinator of the Studies and Research in Development and Psychosocial Intervention Group (GEPDIP, University of São Paulo).

Mariana Guedes de Oliveira Franco is a graduate in psychology from the University of São Paulo (2014) and a Master's student in the post-graduate programme in psychology at the Faculdade de Filosofia, Ciências e Letras de Ribeirão Preto, University of São Paulo (USP-RP). She is a Member of the Studies and Research in Development and Psychosocial Intervention Group (GEPDIP, University of São Paulo).

Cite this article: Franco, M. G. O., Bazon, M. R. 2017. Social Information Processing and Aggravation of Conduct in Young Offenders. International Annals of Criminology 55: 114-131, doi:10.1017/cri.2017.3 